Wartime Housewives and Vintage Women: A. S. Byatt's Ragnarok: The End of the Gods and Reframing Popular Nostalgia

\title{
Leanne Bibby
}

British novelist and critic A. S. Byatt's most recent book Ragnarok: The End of the Gods (2011) is in certain ways more experimental than her better-known novels and stories, although it has one strategy in common with many of them: the texts use the language of myth to test the limitations of patriarchal, historical narratives of the mid twentieth century. This chapter contends that Ragnarok, with its timely depiction of a young girl and her mother living through World War II and the post-war years, can be read productively alongside relevant forms of nostalgia in popular culture (evoking 'vintage' images of wartime- and 1950s-set, domesticated femininity), intensely fashionable by 2011 and remaining so to the present time. Rebecca Bramall has delineated the links between different meanings of 'austerity' in the United Kingdom cogently. She defines austerity as an 'unstable discourse' (2013b, p. 10) variously as a set of coalition government policies and political narratives, as an 'other' than defines left-wing struggle against it, and as an 'object of desire' in popular culture exemplified partly by the craze for 'austerity chic' in fashion, crafts, television, and stylishly 'thrifty' behaviour (2013a, pp. 3-7; 2013b, p. 24). ${ }^{1}$ Byatt's book was published in March 2011, weeks before the wedding of Prince William to Catherine Middleton, and at a time when 'tradition' itself became the height of fashion in the United Kingdom and beyond. At the book's moment of publication, British design trends centred on the Union Jack, bakery businesses flourished as the meal of afternoon tea enjoyed a revival, and street parties simulacra of community-based celebrations of the end of the Second World War-were celebrated again against the background of a new 'age of austerity' heralded by politicians. Many consumers, it seemed, wanted to celebrate in commodified "retro" style, in defiance of 
economic adversity following the 2008 global financial crisis, while also gesturing towards another, past time of such adversity as though from a 'safe' distance.

In the words of novelist Jessica Mann, 'Distance has led enchantment to the popular view of the life most girls and women led in the 1950s' (2013, location 51-57), and this enchantment (applicable also to modern evocations of the 1940s) is a powerful driver of this aspect of popular culture. "Retromania" has become an appealing, eye-catching and lasting trend in popular culture, not least in the self-expression of vintage enthusiasts themselves, some of whose blogs on fashion, cookery and lifestyle have made them into popular and respected voices on their chosen subjects. 'Being well dressed is a form of politeness', ${ }^{3}$ proclaims The Glamorous Housewife on her website of the same name, populated with tips on vintage clothing, 'domestic design', recipes for 'the family' and guests, and advice on marriage, relationships, and good manners - all inflected with pretty imagery and 'inspiration' from the middle decades of the twentieth century (Housewife, 2015, n.p.). This Housewife shares details and pictures of nostalgic hairstyles, jewellery, and décor, alongside a popular post defending her feminist politics: 'I believe that a feminist believes men and women are equal. Period. [...] If I choose to be a CEO of a fortune 500 [sic], I could make that choice' $\left(2012\right.$, n.p.). ${ }^{4}$ In a similar embrace of this paradox - celebrating the notion of choice in order to replicate a time of little choice for women - The Retro Housewife testifies on her blog that 'I was born in the wrong generation, there is no doubt about that. I absolutely idolize the retro housewives. The way they truly loved and embraced their role as a homemaker is so inspiring' (2014, n.p.). This blogger is then quick to stress that she also supports 'women in the workplace and women being successful' - 'Please don't misunderstand' (2014, n.p.). ${ }^{5}$

Several blogs titled 'The Vintage Housewife', originating in the USA, follow a similar pattern, often produced by self-identified housewives and showcasing products, recipes and 
objects of nostalgia for the 1940s and 50s. One 'Vintage Housewife', a prolific blogger since 2008, sports extravagantly curled, peroxide-blonde hair, bright makeup and replica 40s and 50s clothing, as well as a pink-and-white camper van; she writes in 'rockabilly' ${ }^{6}$ slang about her family and the nostalgic locations and events she attends frequently. Like that of The Glamorous Housewife, these blogs also explore problems linked to parenting, relationships and, not infrequently, the outwardly uncertain politics of their lifestyle choices. Another, newer blog titled The Vintage Housewife includes an 'Intro to this Project' section, in which the author writes in response to the stereotypical 'angry feminists' she imagines condemning her for her identification with housewives of the past:

Pipe down, Bra Burners. [...] [Feminism] means that I have the freedom to choose to do whatever I want to do, including studying up on how to be a fifties housewife and then blogging about it. Who knows? Maybe after a few months of following these rules I'll decide that being a fifties woman is completely ridiculous and I'll become an empowered feminist like you. (2013, n.p. $)^{7}$

Here, once more, the blogger emphasises the fluidity of her choice of role that is also a narrative. In the UK, vintage trends have become prominent consumer choices in popular advertising and fashion imagery: the familiar 1940s or 1950s "vintage" woman or housewife, in petticoats or with elaborate "victory roll" curls and headscarf in her hair, has made nostalgia visible and material, particularly in the primarily feminine domains of clothing, cosmetics and homeware. With these objects, evidently marketable and desirable to many, come narratives of women's lives in wartime and the postwar years. Meanwhile, a social and political culture of austerity shapes social life, indeed giving nostalgic design and products a sense of 'appropriateness' for both for those old and these new times, as Bramall observes (2013b, p. 24). Since I began researching this chapter, the number of vintage websites run by companies and individuals has increased noticeably. A large number of personal websites, 
even when their authors describe themselves as favourable to feminist politics, nonetheless seem to testify to a certain, popular disenchantment with feminism, with some women eager to forsake the insecurity of working life (and juggling that life with family responsibilities) and take refuge instead in a seemingly historical notion of proud, resilient and glamorous housewifery.

Vintage trends are consequently troubling for some commentators. Feminist writer Laura Brightwell, blogging in the aftermath of Elizabeth II's Diamond Jubilee celebrations in 2012, raised doubts about popular nostalgia's political and class implications:

This glamorisation of domestic work is potentially troublesome at a time when British women have the most economic freedom we have ever had. That we are, once again, expected to labour over our baking (spotted dicks all round, please!) and to love it, is a bit problematic (2012, n.p.).

Similarly, journalist Tonya Davidson describes the nostalgia growing up alongside popular culture images of the mid-twentieth-century decades as potentially 'retrosexist' because 'dressing in excessively girlish fashions and uncritically embodying the styles of a sexist bygone era are not politically neutral practices' (2014, pp. 26-27). However, in common with Bramall (2013b), Davidson then rightly describes the 'camp femininities' that characterise certain vintage performances of gender, and their subversive potential; this is indeed lost when the 'irony of domestic nostalgia' is lost, for instance when women yearn earnestly to be a character in the glamorised 1960s world of the US TV drama Mad Men (2007-2015), here termed 'nothing more than a fashion shoot' (2014, pp. 26-27).

In her timely memoir The Fifties Mystique (2012) - whose title deliberately echoes that of Betty Friedan's 1963 book The Feminine Mystique, a founding text in second wave feminism which critiques the 1950s mythic "happy housewife heroine" - Mann is correct in stating that that 'distance has led enchantment to the popular view' of the 1950s and 
thereabouts (2013, location 51-57). Still, however, that idea of enchantment is important to many women in ways that demand further, respectful consideration. There is a need to look again, critically, at the precise images of women's lives reproduced by "vintage women": usually imaginative, colourful, and treated as having questionable political authority by the women who assert their choice to be housewives - and maybe, also, to do other things in the future. They draw on an adaptable mythology both of women's pasts and their still, in austere times, uncertain futures, exercising often critical and creative readings of the historical evidence supplied by vintage clothing, recipes and, as referenced in one Vintage Housewife blog, 1940s and 50s home economics textbooks (2014). ${ }^{8}$

The war, its aftermath and related fears and privations are distant from the vintage housewives' narratives, replaced with imaginative "enchantments" of women's realities; this kind of popular nostalgia is for lifestyles more new than old, and reconstituted of selected, older, memorable, and 'appropriate' forms, to borrow Bramall's term (2013a; 2013b), rather than straight "reproductions" of anything original. The vintage bloggers described here make conscious decisions to adopt a style that amplifies their desired femininity, without determining their personal politics or their futures. This style is usually much more brightlycoloured, blowsy and exaggerated than the sombre eye on glamorous but static, melancholy lives portrayed in Mad Men. Bramall and Davidson, then, are right to compare popular vintage in its performative, "ironic" forms to camp, and drag, as nostalgic styles do bring strongly to mind Judith Butler's description of the features and meanings of female impersonation:

In imitating gender, drag implicitly reveals the imitative structure of gender itself-as well as its contingency. Indeed, part of the pleasure, the giddiness of the performance is in the recognition of a radical contingency in the relation between sex and gender in 
the face of cultural configurations of causal unities that are regularly assumed to be natural and necessary. (1990a, p. 187, emphasis in original)

Elsewhere, Butler contends that 'there is no original or primary gender that drag imitates, but gender is a kind of imitation for which there is no original' (1990b; 2004, p. 127, emphasis in original); as is well known, drag thus unsettles notions of essential, natural or ideal gender characteristics. Tellingly, vintage bloggers describe explicitly the roles they choose to inhabit and celebrate, acknowledging tacitly that those roles are not consequences of given gender, but are best "put on" and "played" with escapist joy and creativity (after being bought by way of cosmetics and clothing, a notably un-thrifty aspect of the performance), as any other role they might choose. There is an intense, playful pleasure apparent in vintage bloggers' performances of exaggerated femininity and housewifery, which appear in many cases to have been drawn directly from 1950s advertisements, likely bearing little relation to "real" lives, past or present. This femininity is indeed a mediation between past and present standards of behaviour (Bramall, 2013b, p. 76), and is reconcilable with contemporary feminist politics because it is non-essential, loud, cartoonish, chosen, changeable, and disconnected from "history" itself.

I say these performances are disconnected from history, but they remain linked to it in important ways, a point highlighted by vintage's affinity with historical austerity narratives of the British context in particular, and yet also its resistance to austerity-driven privations following the financial crisis and multiple recessions of recent years. As Helen Davies discusses at length in her chapter in this collection, in David Cameron's infamous 2009 'age of austerity' speech, the Conservative party leader gave an influential but inadequate account of the British past and future. ${ }^{9}$ He combined apocalyptic images of the 'deep, dark clouds over our economy, our society, and our whole political system' with condemnation of 'The highest borrowing in peacetime history' and 'The deepest recession since the war', aligning 
the contemporary moment, seemingly, with historical times of hardship (Cameron, 2009, n. p.). Cameron defended austerity as necessary using a narrative of how 'we' had been here before and had survived, exhorting 'us' personally to 'stick together and tackle this crisis' so that 'our children and grandchildren [would] thank us for what we did for them and for our country' $(2009$, n.p.), thus constructing a future as theoretical and mythological as the past.

Cameron's myth-spinning, however, inadvertently gestured towards more progressive, effective ways of re-reading the past. In light of the frightening economic realities of recessions and austerity, popular, vintage culture's nostalgia is easily criticised as a naive and politically questionable retreat from challenging times, especially when retromania appears to be primarily a feminine, white and middle-class trend emblematised by not-inexpensive Cath Kidston knitting bags ${ }^{10}$ and time-consuming, decorative baking. But crucially, the colourful retromania of the few years since Cameron's speech is conceptually, critically and imaginatively engaged with austerity culture in a way his rhetoric was not. Vintage imagery translates historical narratives selectively and inventively into bright, pleasurable and malleable objects of a politically changed and changing present day, and symbols of hopedfor futures. Using vintage websites such as those described earlier, for example, families facing smaller incomes and higher prices can access plentiful information on saving money with ease, while cupcakes and 'upcycling' of vintage clothing ${ }^{11}$ represent affordable luxuries (for some).

As well as inhabiting roles, adherents of vintage demonstrate an awareness of how they can and do re-narrate selected histories in the present day, in order to alter futures for the better. In their consciousness of their own narratives and creative potential, they become agents of mythopoeia, defined as myth-production or myth-expansion (Baldick, 2008, n.p.). A. S. Byatt's Ragnarok intervenes in a cultural moment of intense popular nostalgia to contribute to a reframing of thinking about gender and wartime/postwar nostalgia, because 
the book explores directly the role of myth narratives in remembering and re-narrating gendered histories. Conventionally, but tellingly, the Oxford English Dictionary defines a 'myth' as a story seeking to explain aspects of a society's past, often an imaginative or fanciful version of that past (2003, n.p.). In addition to this familiar definition, Byatt's writing theorises utilise myth partly as a distinctly feminist mode of representing pasts as well as desired futures, in relation to, but not limited by, dominant historical narratives. Her writing conceptualises "nostalgia" not as a backward-looking belief in supposedly better, bygone times, but as an inventive impulse. Mediated usually by critically-minded, creative, female protagonists, Byatt's nostalgias and myths are thus not straightforward carriers of patriarchal tradition; instead her texts incorporate a sense of the power of narrative to do their feminist work.

In the following extract, from Byatt's 1978 novel The Virgin in the Garden, young intellectual Frederica Potter becomes aware of the postwar narratives of her recent life and its historical contexts - notably, its feminine, pleasurable aspects - as readable, changeable phenomena; moreover, her readings enhance those narratives' significance:

The haberdashery had always been a favourite haunt. They had come here in their early days for lace collars for party dresses, ribbons for hair, tape, elastic, buttons and press-studs. Frederica in 1953 was disposed to see these visits as tedious rituals, although she saw that it might be possible to see them otherwise, with a kind of Dickensian nostalgia for the details of a vanished life, which was, in fact, how in 1973 she came to see them. (Byatt, 1978, p. 251)

Several of Byatt's other fictions utilise the language of myths and folktales explicitly to represent women's narrative power over their culture and its "enchantments". In 'The Story of the Eldest Princess, a short tale included in the volume The Djinn in the Nightingale's Eye (1994), the 'eldest princess' of the title embarks on a quest that leads her to 'outwit' the story 
of a princess's traditional, sexual destiny: "“You are a born storyteller," said the old lady. "You had the sense to see you were caught in a story, and the sense to see that you could change it to another one"' (Byatt, 1994, pp. 66). These protagonists discover a gift for mythopoeia, as a response to the unfixed narratives they inhabit and that have been officially organised patriarchally.

Byatt's Ragnarok depicts a young, female reader of Norse myths, 'the thin child', who uses the mythopoeic potential of reading, thought, memory, and speculation to disintegrate the narrative of her own narrow, uncertain life in the 1940s, as well as a looming, domestic future mirroring that of her frustrated, Cambridge-educated mother (Byatt, 2011, p. 3). The text "looks back" on the many dangers of women's lives at this time not normally confronted by nostalgic forms of popular culture, and does this not with bleak realism but with methods of inventive 'enchantment' vintage women might find familiar. Ragnarok quickly announces its concern with the mythic, narrative forms of history: 'There was a thin child, who was three years old when the war began. She could remember, though barely, the time before wartime when, as her mother frequently told her, there was honey and cream and eggs in plenty' (2011, p. 3). Byatt was born in 1936 and, like her protagonist 'the thin child', inherited a book of Norse myths by Wilhelm Wägner titled Asgard and the Gods from her university-educated mother; Ragnarok is thus a multimodal experiment in rewriting "real" pasts. Formally, it is far removed from Byatt's long, historical bestsellers Possession: A Romance (1990) and The Children's Book (2009), being composed in three sections: the story of 'the thin child' told in the spare, precise language of folktales, a central retelling of the Norse myth of the end of the world and of the gods, and finally a critical reflection on that retelling by the author herself. The text challenges conventional narratives of the past using multiple, mythic narratives both interrupted and complemented by a myth of apocalypse - a destruction of old ways, relished by the 'thin child' herself. 
Ragnarok's feminist mythopoeia and focus on women of the generation idolised in vintage culture reveal the often complex feminist functions of women's relationship to historical narrative and nostalgia, illuminating why they might rewrite "memory" itself. In common with some of the vintage bloggers I have mentioned, Byatt has publicly disassociated herself from overt feminist agendas, while defending her work's feminist politics. She has contended that Possession, with its narratives of women artists and intellectuals thinking and writing their way toward autonomy, is an example of a 'very, very feminist book', while on the other hand, she has expressed her wish not 'to be ghettoized by modern feminists into writing about women's problems': 'I think in metaphors, not in propaganda' (Tredell, 1994, pp. 60-61). Byatt's work prioritises feminist narrative functions above declared agendas, an idea that proves to be equally liberating for modern vintage women who celebrate interchangeable narratives. For Byatt's own critically-minded women characters, "traditional values" are myths to be negotiated among multiple versions of feminine life. I would argue that this is part of popular culture's current, potentially 'progressive politics of austerity', suggested by Bramall (2013b, p. 30). In Ragnarok's final section, 'Thoughts on Myths', Byatt isolates myth as a concept, explaining that the word 'myth' 'comes from "muthos" in Greek, something said as opposed to something done' (2011, p. 157). 'Saying', telling, producing and reproducing culture, are key. Ragnarok's thin child understands her world through mythic narratives passed on primarily by her readermother; the child learns, then, to understand such narratives subjectively in order to improve her experience of the Second World War.

The most significant of these narratives concern the genders and the spheres the child and her mother inhabit: her mother's life is 'paradoxical. Because there was a war on, it was legally possible for her to live in the mind, to teach bright boys, which before the war had been forbidden to married women' (Byatt, 2011, p. 4). The thin child narrates disheartening 
realities into bearable stories: 'Her mother was more real, and kinder, when it was a question of grouped letters on the page' and her fighter pilot father 'was in the air, in the war, in Africa, in Greece, in Rome, in a world that only existed in books' (2011, p. 4). This dismissal of the 'real' is more than simple, "looking-back" nostalgia for childhood coping mechanisms; Byatt also mobilises a variety of myths, from apocalyptic notions of the war ('They faced the end of the world they knew', p. 4) to altered versions of the real world, suggesting vital alternatives to the cultural myths of 'tradition' that, for example, formerly confined the thin child's educated mother to her home. More than a subject of history, and of the dominant culture and its mindsets, the thin child is now an agent of them.

Laurence Coupe's descriptions of mythopoeic language and forms (1997) can here contextualise the thin child's imaginings of her life and family. Coupe theorises myths similarly to Byatt's texts, as stories featuring archetypes or recurring figures and themes, some laying claim to paradigmatic status, for instance, images of the home front housewife and the hero soldier. Individual myths gain their apparent power and authority from their inclusion of recognisable paradigms, but also, as Coupe stresses, from their reworking of those paradigms. Myths comprise no truly 'pure' paradigms because 'Exceptions to, and contradictions of, any particular paradigm are endless' (1997, pp. 5-6). Whatever impression the myth might give, there are endless potential variations on its figures. Thus, the conservative, nostalgic ideal of the housewife is not actually an ideal, but a very specific myth to be read in those terms. This provides vital background to the early twenty-firstcentury impulse to recall the past imaginatively.

Coupe cites the philosopher Paul Ricoeur in emphasising mythic narrative's 'exploratory significance', hugely important within a feminist reading of the cultural histories which Byatt negotiates. Archetypes and paradigms within mythology signal an apparent 
hierarchy, for example in placing the wartime housewife within the home (or the home front) and away from the public sphere; however, this is a specific, not universal, scenario:

[...] myth may imply a hierarchy, but it also implies a horizon: it is 'a disclosure of unprecedented worlds, an opening on to other possible worlds which transcend the established limits of our actual world' (Ricoeur 1991: 490). In other words, while myth may be paradigmatic, and while it may imply a social and cosmic order, or perfection, it also carries with it a promise of another mode of existence entirely, to be realised just beyond the present time and place. (Coupe, 1997, pp. 8-9)

The thin child's wartime narratives are explicitly mythopoeic, in Coupe's sense: she escapes dangers by looking for the 'horizons' at the edge of myths and testing paradigms' limitations. She fears her housewife mother's domestic, feminine fate, but this reality is a problem with potential, narrative solutions. Sensing alternatives, she reads the chaotic myths in Asgard and tells complementary stories to answer her realities and to feel secure - as indeed might any modern, critically-minded woman uncertain of her fate. Byatt's possible nostalgia for her childhood reading is part of this creative, progressive mythopoeia. Roberta Rubenstein writes that nostalgia 'encompasses something more than a yearning for literal places or actual individuals. While homesickness refers to a spatial/geographical separation, nostalgia more accurately refers to a temporal one' $(2001$, p. 4). In the thin child's narrative, as in the outputs of nostalgic writers and businesspeople today, "time" fills with desired spaces and objects. Ragnarok instructs that nostalgia is not only imaginative by definition, but empoweringly so. The text requires and exploits memory's personal-historical paradigms - home, mother, father, past and future - to demonstrate that these are meaningful, but no longer entirely literal.

Byatt's language is dreamlike, surreal and sensuous, suggesting nostalgia whilst indicating nostalgia's powers in the mind of a critical reader: 
The picture [a scene from Asgard] gave the child an intense, uncanny pleasure. She knew, but could not have said, that it was the precise degree of formlessness in the nevertheless scrupulously depicted rocks that was so satisfactory. The reading eye must do the work to make them live, and so it did, again and again, never the same life twice, as the artist had intended. She had noticed that a bush, or a log, seen from a distance on her meadow-walk, could briefly be a crouching, snarling dog, or a trailing branch could be a snake, complete with shining eyes and flickering forked tongue. (2011, p. 10)

The 'ordinary paradise of the English countryside' (Byatt, 2011, p. 3) becomes a flat and deceptive paradigm next to the vividly drawn, Norse scene, revealing the frightening, but exciting, possibilities at reality's mythic horizons. Myth makes her world larger than her home or her geographical area, threatened by war: 'That book was an account of a mystery, of how a world came together, was filled with magical and powerful beings, and then came to an end. A real End. The end' (2011, p. 9). Endings mean that traditions, dependent on concepts of time's progress and a future benefiting from the ways of the past, lose some of their authority. The thin child recalls that her mother was 'gallant and resourceful in wartime' (sincere praise, but also a pointed reference to the historical and modern cliché of heroic home front women), and that she also 'did inhabit the countryside and its stories' (2011, pp. 150-151). The parameters of the mother's feminine 'story' shift with her work as a teacher, which in her daughter's telling brings her into the messy nature of the countryside with its 'hedgehog dripping fleas' and 'vast slimy clumps of frogspawn’ (2011, pp. 151-152), instead of the classroom.

The patriarchal mythology underpinning and restricting the women's lives is changeable because of wartime uncertainties, but that war limits their freedom: the thin child's mother teaches 'bright boys' (my emphasis) only, and temporarily. This is another 
haunting form of 'the end of the world'. Despite the 'despair [the thin child] did not know she felt' (2011, p. 4), imaginatively, she then finds vital possibilities within disorder:

This way of looking was where the gods and giants came from.

The stone giants made her want to write.

They filled the world with alarming energy and power. (2011, p. 10)

This 'way of looking' may reject provisional ideas of the past and the future (2011, p. 10). Traditions and "pure" paradigms, linked to the sense of linear history disrupted by war, operate according to conventions. In Ragnarok, mythopoeia is paradoxically, challengingly, both a part of patriarchal traditions and a mode of resistance against them - it writes myths of "appropriate" life trajectories, while showing their limits. The thin child considers the Norse tales' mysteriousness in Asgard and the Gods in terms of the conventions of stories. Exhilaratingly, she 'knew enough fairy stories to know that a prohibition in a story is there to be broken' (2011, p. 22); the tales' images 'were coiled like smoke in her skull, humming like dark bees in a hive' (2011, p. 31). These last metaphors suggest the darkness and destruction attracting the thin child, even while she looks for refuge from her 'despair'. Stories allow her to contemplate wartime destruction safely, as 'they didn't live in her, and she didn't live in them' (2011, p. 31). Destruction here means both physical death and loss (symbolised in the thin child's fear for her father, and her damage to unopened flower buds) and the desirable destruction of patriarchal narratives as ideas, only. The thin child watches soldiers pass through her small town in convoys and imagines her airman father as part of the Norse god Odin's Wild Hunt: this is 'a good story' because 'meaning, fear and danger were in it, and things out of control' (2011, p. 41). If things are indeed out of control, then the heroic, patriarchal logic of her father going away and not returning - deemed a noble sacrifice, officially - can be subverted. 
Ragnarok's sections are named emblematically, as the thin child navigates uncertain historical narratives alongside myth's liberating inordinateness: between 'A Thin Child in Wartime' and 'The End of the World', and 'Ragnarök' and 'The Thin Child in Peacetime', there is a single-paragraph section titled 'The Thin Child in Time'. The thin child's imaginative dependence on myth has often removed her from any sense of time: 'Imagining the end of things, when you are a child, is perhaps impossible' (Byatt, 2011, p. 127). Also, her almost ahistorical inner life is a rejection of other temporal endings. Her own narrative escapes her control: she has nightmares of deaths by hanging, now a part of the history she has partly ignored and partly reimagined, but she does not acknowledge that she understands death as a 'fact' (2011, p. 127). Her other, crucial fear asserts itself here, of a future of 'dailiness' as a housewife, or the boredom of domestic repetition, before the book's retelling of 'Ragnarök' itself. In this final, Norse tale of apocalypse, time and order are suspended, the earth freezes and at first the 'men' of the earth are 'excited' because this 'was a test of strength. A test of manhood' (2011, p. 132). Gendered narratives of strength are then nevertheless destroyed, with everything else. The narrative itself breaks into fragmentary sentences and ideas: 'Wind Time, Wolf Time, before the World breaks up. / That was the time they were in' (2011, p. 135).

'The Thin Child in Peacetime' requires this apocalypse narrative as 'a form of knowledge itself', to know that the world's discourses are fragile, uncertain, specific and changeable; she reads Asgard selectively because she "needed the original end, the dark water over everything', unchanged by later Christian 'contamination' with the return of gods and men to inhabit the world (2011, p. 147). She needs this myth because her story's positive “ending", her father's return and her family's return home, is no ending at all and is tinged with sadness owing to her fear of a future of boredom. She treasures a set of books, more feminine than Asgard, 'of Flower Fairies with well-written verses and elegant pictures. 
Dogrose, Lords and Ladies, Deadly Nightshade, violets, snowdrops and primroses' (2011, p. 152). In these lines as in the Norse myths, beauty and poison coexist, and order with unbound, unpredictable danger. Furthermore, the return to peace and "order" slowly devastates the thin child's mother and provides a specific fate for her daughter to resist:

The long-awaited return took the life out of the thin child's mother, the thin child decided many years later. Dailiness defeated her. She made herself lonely and slept in the afternoons, saying she was suffering from neuralgia and sick headaches. The thin child came to identify the word 'housewife' with the word 'prisoner'. (2011, p. 152)

This insight into her mother's pain is perhaps the book's central vindication of mythopoeia as a mode of survival. The child's mother is a 'prisoner' of a pre-set narrative of feminine life, but importantly, the 'housewife' is a paradigm that has never been made 'pure' or 'perfect'. The thin child's mother is set alongside the unpredictable, androgynous god Loki, whom no structure - physical, biological or cultural - could contain. For all her earlier education, her responsibilities to home and family are totalising and she unfortunately has no mythopoeia at her disposal. Nonetheless, crucially, she has handed her books down to her daughter, whose future is a narrative the thin child is equipped to rewrite.

Ragnarok does not end with the end of the war, because such an ending would belong to the grand narrative - Jean-François Lyotard's term for overarching, explanatory theories of the world (1984) - of war victories as good triumphing over evil, within a framework of masculine heroism and patriarchal glory. For the thin child and her mother, Jessica Mann's phrase is acerbically appropriate: in 1945, 'peace broke out' (2013, location 66) and the patriarchal order of the world seemed set to be restored. Byatt does not finish the story with a drive towards the 'perfection' of a 'finished' myth. The thin child's mythopoeic reading of her world contests the threat of the 'dailiness' apparently destroying her reading, thinking mother, and she continues her active, imaginative reading of Asgard. Unlike the mythographers who 
would 'perfect' myths and assign them authority, however, the thin child cherishes the idea of the possibilities on the other side of dailiness:

A gate closed in her head. She must learn to live in dailiness, she told herself, in a house, in a garden, at home, where there was butter again, and cream, and honey, good to taste. She must savour peacetime.

But on the other side of the closed gate was the bright black world into which she had walked at the time of her evacuation. The World-Ash and the rainbow bridge, seeming everlasting, destroyed in a twinkling of an eye. The wolf with his hackles and bloody teeth, the snake with her crown of fleshy fronds, smiling Loki with fishnet and flames, the horny ship made of dead men's nails, the Fimbulwinter and Surtr's conflagration, the black undifferentiated surface, under a black undifferentiated sky, at the end of things. (Byatt, 2011, p. 154)

This is the frightening, barely knowable and exhilarating narrative that the thin child has 'made' out of the myths in Asgard and the war. She cannot 'savour peace-time' and its promised economic plenty because it signifies a return to other kinds of "order" beside peace in Europe, that would define and trap her female mind and body (2011, p. 154). The above images of the Ragnarök apocalypse respect no grand narratives of order, instead switching fluidly between colours and darkness, mythical trees, gods and animals, and contrasting with the softer sentences and sounds depicting mythical English gardens and un-rationed luxuries. There, the thin child's story reaches a stop, not an ending, without submission of the girl or the narrative to a fixed future or set of values.

\section{Conclusions: Feminist Mythopoeia and Horizons}

The thin child fears the 'dailiness' of housewifery as a danger of postwar life (2011, p. 154), but Byatt leaves her with the imaginative power to resist it - a very similar imaginative 
potential deployed within the early twenty-first century's popular nostalgia for the same historical era. In Ragnarok, Byatt's feminist mythopoeia replaces the same patriarchal notion of cultural, "shared" memory that delineates conventional nostalgia as a simplistic construction of an idealised past, rather than a creative path towards other possibilities exemplified by many modern vintage and wartime housewives' embrace of identities "between" the historical housewife and modern feminist (Hollows, in Bramall, 2013b, p. 112). Recognition of a similarly creative mythopoeia at work in fashionable nostalgia or vintage culture reveals this culture to be a multiplicitous set of resisting readings of the past, whose functions would be undermined by any drive towards "perfect", finished myths. Conventional nostalgia's wish for unity (and belief in certain "lost" standards and values) is exactly that: a wish that historical discourses, multiple accounts of the past, cannot fulfil. Byatt's fictions expose nostalgia's inventive, discursive work, so that Frederica Potter's memories of the 1950s haberdashery are replete with new, charming significance because she is a powerfully critical reader of histories. Ragnarok scrutinises how contemporary culture's nostalgic narratives simultaneously connect with and critique modern, political discourses of the present age of austerity: both appeal to wartime and postwar narratives' paradigmatic images and to their limitations, especially those with antifeminist implications of oppressive "tradition".

Coupe, referencing literary critic Kenneth Burke's theories, advises readers of any myth to "consider what it is "doing" as well as what it is "saying": that is, to bear in mind the pragmatic impulse which would have occasioned it in the first place' (Coupe, 1997, p. 7). To privilege a certain myth or interpretation of that myth is to project 'a certain idea of perfection onto material that may have more practical functions' (Coupe, 1997, p. 7). Byatt's fiction demonstrates this with her repeated motif of dailiness, feared by her women protagonists who resist it, as readers may, by recognising its specificity among other 
narratives. Vintage culture, then, asserts its own critical "imperfection" and its "practical functions" by omitting images of housewifery's dailiness in favour of fantastical alternatives. Today's fashionable "vintage women" need not contemplate wartime's physical or ideological dangers, and thus may not need to reference Norse mythology, but they are no less concerned than the thin child with finding the horizons of mythic narratives - of history, femininity, work, family - in order to project new futures. The nostalgias promulgated by these writers, entrepreneurs, public figures and followers of the trend, including the bloggers I referred to earlier, are part of the creation of pragmatic mythologies of the past's relationship to the present, a process similar to the one isolated strikingly in Ragnarok.

Reading vintage culture as mythopoeic reveals its unfixed political allegiances, for instance in its depictions of housewives and domesticity. The thin child fears mindless, feminine dailiness, as Byatt has said she did herself:

this was to do with the fate of women in my generation. I was terrified of being shut in a kitchen with a washing tub and, later, a washing machine. I was terrified of the repetitiveness of ordinary things, which can be made to seem glamorous in a novel. (Byatt, 2004, p. 148)

The 'eldest princess' of Byatt's short tale, too, avoids marriage to a handsome woodcutter when she realises that a form of dailiness has killed his previous wives (Byatt, 1994, p. 60). Dailiness is not housewifery itself but rather a fixed, repetitive version of it, one of patriarchy's historical victories. Modern vintage culture does not really depict dailiness, and instead of merely omitting or disavowing women's historical problems, vintage culture relies on the multiple, narrative nature of the historical imagery and myths underpinning it. Again, vintage's proponents fill their pasts, presents and futures with desired objects. Ragnarok dramatises an analogous process by way of its 'internal', imaginative critique, examining and utilising myth in the ways I have described, and by exposing the deceptive 
historical paradigms on which a narrow, prescriptive form of nostalgia (this is the proper, 'traditional' way to do things) would depend.

The numerous "vintage" websites and personal blogs now online, and books published, of the type that might fuel fears of growing antifeminism, actually reveal promisingly multiplicitous adaptations of the paradigms of the wartime and postwar housewife and the dailiness they obscure. These websites' owners may or may not be declared housewives, but are usually educated, articulate, artistic and of course, highly webliterate; they are agents of mythopoeia, whether feminists in stated agenda or, in practice, via the transforming discourses their images suggest. Furthermore, beside their glamorous (re)constructions and explorations of feminine identity, useful narratives of resisting austerity itself remain prominent. On her website wartimehousewife.com, under the heading 'Old Values in Modern Times', the 'Wartime Housewife' herself, Biff Raven-Hill, sets out her mission statement of keeping certain "traditional values" alive for the benefit of economically difficult modern times; values centred on the home, frugality, avoiding waste and buying second hand (2013, n. p.). The website and its construction of the Housewife's "wisdom" and authority in these matters (that are, after all, based on much laudable economic advice) depend on our acceptance of the virtue of "past" wisdom and of certain narratives of the Second World War's heroic, home front women. However, the site's substantial archive of advice on saving money, parenting and home cooking is presented not in terms of straightforward nostalgia for the past, but in terms of ideas of taking responsibility for the present that do not depend on any real idealisation of an essential, traditional femininity. This and other 'neo-traditional' (Miller, 2013) narratives works within modern myths of the past and also the future, turning historical narratives into suggestions of other modes of existence, 'to be realised just beyond the present time and place' (Coupe, 1997, pp. 8-9). They adapt "traditional values" by looking to the hardships of the past (including the time before the 
modern women's movement) while re-using its glamorous, although helpfully dislocated, stereotypes.

In common with A. S. Byatt's mythopoeic fictions, proponents of contemporary vintage culture use mythopoeic forms of historical narrative to constitute what Byatt's thin child regarded as 'a form of knowledge' (2011, p. 147) with which to process a troubling reality: new ways of appearing, living and coping in an era of austerity. Many women agents of nostalgia and mythopoeia today, whether novelists, journalists or bloggers, supply colourful, optimistic and creative myths of femininity, resourcefulness, work and politics, which should not be dismissed as simply retrograde and backward-looking. Rather, they often locate the horizons at the edge of patriarchal historical paradigms by making their vintage images purposefully as excessive, ironic and inventive as "new" vintage products like billowing Vivien of Holloway ${ }^{12}$ dresses. These discourses do not constitute a serious resistance to feminist politics in times of austerity, but instead are a proliferation of knowledges located outside the "lines" posited by "traditional values", and prizing historical mythopoeia: the hopeful narrative that we have indeed been here before, have survived and will survive again, in different ways. Where this mythopoeia is feminist in aim or function (or both), it constructs a feminist literacy that is especially necessary in times of austerity: one that looks backwards in time to find or create ways of living, working and thinking that sustained previous generations, but which can combine comfortably with the gains of modern women's movements. Byatt's Ragnarok proposes ways of reading nostalgias that allow its adherents to place themselves imaginatively in versions of the past while utilising feminism's critical modes; there, moreover, they are never completely outside the present moment in which feminist politics are available to them in every aspect of life.

\section{Notes}


1 My work in this chapter follows Bramall's thorough examinations of the relationships between 'austerity' and popular culture in her article 'Popular Culture and Anti-Austerity Protest' (2013a) and her book The Cultural Politics of Austerity: Past and Present in Austere Times (2013b). Several chapter headings in Bramall's book indicate our shared concerns and consideration of similar phenomena (such as vintage culture and its adherents), for instance 'The Past in the Present: History, Memory, Ideology, and Discourse' and 'Turning Back Time: Feminism, Domesticity, and Austere Femininities'. Bramall analyses current meanings of the historical 'austerity Britain' and the appeal of the 'material and affective attributes' of discourses of austerity (2013a, p. 8), such as consumer culture, whereas I pursue the narrative aspects of this relationship of the past to the present through A. S. Byatt's appropriation of historical accounts' mythic qualities. Bramall's book is especially useful for its very detailed and illuminating review in Chapter 6 of feminist perspectives on the 'housewife' figure (2013b, pp. 111-136).

2 The edition of The Fifties Mystique referenced here is the 2013 electronic version, read on a Kindle device.

3 See The Glamorous Housewife's ‘About' section: $\langle\underline{\text { http://theglamoroushousewife.com/about/> }}$.

4 See the post titled 'Can you be feminine and a feminist?', 10 December 2012, at The Glamorous Housewife: <http://theglamoroushousewife.com/2012/12/can-you-be-feminineand-a-feminist/>.

5 See The Retro Housewife's ‘About The Retro Housewife' section: <http://theretrohousewifelife.com/about/>.

6 'Rockabilly' refers to 'early American pop music that originated in the American South in the 1950s; it combined elements of country music with rock and roll' and was 'typified by Elvis Presley's recordings in 1954-5 for Sun Records' (Gloag, 2015, n.p.). Currently, the term 
is more likely to refer to the 1950s-style, nostalgic aesthetic in dress, cosmetics, and décor which draws on American imagery.

7 See: 〈http://myquestfordomesticity.blogspot.co.uk/p/intro-to-this-project.html >.

8 See the post titled 'New Year, New Project' at The Vintage Housewife:

<http://myquestfordomesticity.blogspot.co.uk/2013/01/new-year-new-project.html>.

9 A transcript of David Cameron's full speech can be accessed here:

<http://www.theguardian.com/politics/2009/oct/08/david-cameron-speech-in-full>

10 See the website of the successful clothing and homeware retailer Cath Kidston, for examples of how popular nostalgia can inform design, if not politics:

<http://www.cathkidston.com>.

11 'Upycling' is used here in the context of second-hand clothing, particularly previous decades' fashions, which shoppers purchase in vintage shops and incorporate into new 'looks' (sometimes altering them by hand). British television presenter Dawn O'Porter nurtured this trend in her 2014 Channel 4 programme This Old Thing: The Vintage Clothes Show, in which she advised guests and viewers on choosing vintage clothes, and also on sewing and alterations. O'Porter published a tie-in book on the subject, This Old Thing: Fall in Love with Vintage Clothes (2014). O'Porter's series and book, combining a thrifty ethos with an injunction to spend (money and time) but spend wisely, engaged with an established trend exemplified by public figures such as Kirstie Allsopp, the author and presenter of a number of vintage and 'handmade'-themed books and programmes of recent years.

12 The British nostalgic clothing retailer, Vivien of Holloway, offers creative 1940s and 1950s facsimiles: 〈http://www.vivienofholloway.com>.

\section{Bibliography}

Baldick, C. (2008) The Oxford Dictionary of Literary Terms. [online] Oxford: Oxford 
University Press. Available from: <http://www.oxfordreference.com> [Accessed: 12 February 2015].

Bramall, R. (2013a) 'Popular culture and anti-austerity protest.' Journal of European Popular Culture, 3 (1), pp. 9-22.

- (2013b) The Cultural Politics of Austerity: Past and Present in Austere Times. Palgrave Macmillan Memory Studies. Basingstoke: Palgrave Macmillan.

Brightwell, L. (2012) Is ‘cupcake feminism' all empty calories? The F word: contemporary UK feminism, 10 August. [online] Available from:

<http://www.thefword.org.uk/features/2012/08/cupcake_feminis $>$ [Accessed: 12 February 2015].

Butler, J. (1990a) Gender Trouble. $2^{\text {nd }}$ ed. Abingdon, Oxon: Routledge.

- (1990b) Imitation and Gender Insubordination. In: Salih, S. and Butler, J. eds. (2004) The Judith Butler Reader. Malden, MA: Blackwell Publishing.

Byatt, A. S. (1978) The Virgin in the Garden. $3^{\text {rd }}$ ed. London: Vintage.

- (1990) Possession: A Romance. $2^{\text {nd }}$ ed. London: Vintage.

— (1994). The Story of the Eldest Princess. In: Byatt, A. S. The Djinn in the Nightingale's Eye. $2^{\text {nd }}$ ed. London: Vintage.

- (2009) The Children's Book. London: Chatto and Windus.

- (2011) Ragnarok: The End of the Gods. Edinburgh: Canongate.

— and Frosh, S. (2004) 'Conversation between A. S. Byatt and Stephen Frosh'. Psychology and Psychotherapy: Theory, Research and Practice, 77 (2), pp. 145-159.

Cameron, D. (2009) Tory spring conference speeches in full. politics.co.uk [online]. Available from: <http://www.politics.co.uk/comment-analysis/2009/04/27/tory-springconference-speeches-in-full> [Accessed: 12 February 2015]. 
Cath Kidston [online]. Available from: <http://www.cathkidston.com> [Accessed: 12 February 2015].

Coupe, L. (1997) Myth. London: Routledge.

Davidson, T. (2014) 'Dishing Out Domestic Nostalgia'. Herizons, Fall 2014, pp. 24-27.

Friedan, B. (1963) The Feminine Mystique. New ed., 2010. London: Penguin.

The Glamorous Housewife [online]. Available from:

<http://www.theglamoroushousewife.com> [Accessed: 12 February 2015].

Gloag, K. 'rockabilly'. The Oxford Companion to Music. Ed. Alison Latham. Oxford Music Online. [online] Available from: <http://www.oxfordmusiconline.com> [Accessed: 12 February 2015].

Lyotard, J. (1979) The Postmodern Condition: A Report on Knowledge. Translation: University of Minnesota, 1984. Manchester: Manchester University Press.

Mann, J. (2012) The Fifties Mystique. Digital ed., 2013. St. Clement, Cornwall: Summaries and Plain Digits. Available from: < http://www.amazon.co.uk/The-Fifties-Mystique$\underline{\text { Jessica-Mann- }}$ ebook/dp/B00CKCC27U/ref=sr_1_1?s=digitaltext\&ie=UTF8\&qid=1386752168\&sr=1-

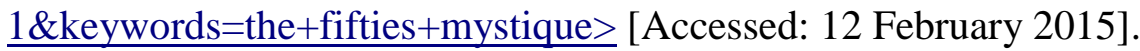

Miller, L. (2013) The retro wife: feminists who say they're having it all - by choosing to stay at home. New York magazine. [online] Available from: <http://nymag.com/news/features/retro-wife-2013-3/index2.html > [Accessed: 12 February 2015].

Myth. (2003). In: Oxford English Dictionary. [online] Available from: <http://www.oed.com $>$ [Accessed: 12 February 2015].

O'Porter, D. (2014) This Old Thing: Fall in Love with Vintage Clothes. London: Hot Key Books. 
- (2014) This Old Thing: The Vintage Clothes Show. [television] London: Channel 4.

The Retro Housewife Life. [online] Available from: 〈http://theretrohousewifelife.com/>

[Accessed: 12 February 2015].

Rubenstein, R. (2001) Home Matters: Longing and Belonging, Nostalgia and Mourning in Women's Fiction. Basingstoke: Palgrave Macmillan.

Tredell, N. (1994) A. S. Byatt. In: Conversations with Critics. Manchester: Carcanet Press. The Vintage Housewife. (2008) [online] Available from:

<http://thevintagehousewife.blogspot.co.uk > [Accessed: 12 February 2015].

The Vintage Housewife. (2013) [online] Available from:

<http://myquestfordomesticity.blogspot.co.uk/> [Accessed: 12 February 2015].

Vivien of Holloway. [online] Available from: 〈http://www.vivienofholloway.com $>$

[Accessed: 12 February 2015].

The Wartime Housewife. (2013) [online] Available from:

<http://www.wartimehousewife.com> [Accessed: 12 February 2015]. 